\title{
МІНЕРАЛЬНИЙ СКЛАД КОРЕНЕПЛОДІВ ТА ПЛОДІВ ПАСТЕРНАКУ ПОСІВНОГО (РАSTINACA SATIVA L.) СОРТУ “ПЕТРИК”
}

Вступ. Збереження здоров'я людини за умов екозалежних патологій - найактуальніше питання сучасної медицини та фрармації. Наявність в організмі певних мінеральних речовин у відповідній кількості одна з умов підтримання та збереження здоров'я людини. Незважаючи на те, що мінеральні речовини не мають енергетичної цінності, як білки, жири і вуглеводи, багато фрерментативних процесів в організмі не можливі без їх участі. Таким чином, найважливіші фрункції живого організму - реалізація генетичної інфрормації, утворення субклітинних структур, метаболічні процеси, вироблення енергії, фрункціонування всіх органів і систем - залежать від кількісного та якісного вмісту в організмі мінеральних речовин.

Мета дослідження - визначити макро- і мікроелементний склад коренеплодів та плодів пастернаку посівного сорту “Петрик".

Методи дослідження. Якісний склад та кількісний вміст макро- і мікроелементів висушених коренеплодів та плодів пастернаку посівного (Pastinaca sativa L.) copmy "Петрик" визначали методом атомноемісійної спектроскопії з фотографрічною реєстрацією в Науково-технологічному комплексі "Iнститут монокристалів" НАН України.

Результати й обговорення. Отримані експериментальні дані щодо макро- і мікроелементного складу коренеплодів та плодів пастернаку посівного свідчать про наявність у них не менше 19 елементів. У найбільшій кількості в коренеплодах містяться калій (2010,00 мг/100 г), кальцій (435,00 мг/100 г), магній (300,00 мг/100 г), натрій (270,00 мг/100 2), фросфрор (235,00 мг/100 2), у плодах переважає калій (1510,00 мг/к2). Крім того, в коренеплодах пастернаку посівного виявлено достатньо високий вміст цинку (13,40 мг/100 г). Вміст інших елементів становить менше 0,1 мг/100 г.

Висновки. Методом атомно-емісійної спектроскопії в коренеплодах та плодах пастернаку посівного сорту "Петрик" виявлено не менше 19 макро- і мікроелементів. У коренеплодах пастернаку посівного кількісно переважають калій (2010,00 мг/100 г), кальцій (435,00 мг/100 г), магній (300,00 мг/100 г), у плодах більше калію (1510,00 мг/100 2). Результати проведених досліджень будуть використані для подальших фрітохімічних досліджень сировини пастернаку посівного та розробки нових лікарських засобів на його основі.

КЛЮЧОВІ СЛОВА: пастернак посівний; макро- та мікроелементи; атомно-емісійна спектроскопія.

ВСТУП. Збереження здоров'я людини за умов екозалежних патологій - найактуальніше питання сучасної медицини та фрармації. Наявність в організмі певних мінеральних речовин у відповідній кількості - одна з умов збереження здоров'я людини. Незважаючи на те, що мінеральні речовини не мають енергетичної цінності, як білки, жири і вуглеводи, багато ферментативних процесів в організмі не можливі без їх участі. Таким чином, найважливіші фрункції живого організму залежать від кількісного та якісного вмісту в організмі мінеральних речовин $[1,2]$.

На атомарному рівні організм будь-якої живої істоти являє собою упорядкований набір атомів хімічних елементів періодичної системи Менделєєва. Чотири елементи є органогенами оксиген, карбон, гідроген та нітроген, які становлять основу макромолекул білків, амінокислот, () Ю. Є. Шиморова, В. С. Кисличенко, В. Ю. Кузнєцова, 2017. нуклеотидів ДНК, цукрів тощо. Макроелементи кальцій, фросфор, калій, натрій та магній життєво необхідні для підтримки гомеостазу внутрішнього середовища. Інші хімічні елементи, які містяться в організмі в кількості 10-3-10-12 \% від маси тіла, є мікро- та ультрамікроелементами, але абсолютно необхідні для нормального перебігу більшості процесів життєдіяльності [3]. Мікроелементи $€$ каталізаторами обмінних процесів і відіграють важливу роль в адаптації організму в нормі й за умов патології.

Важливо пам'ятати, що мінеральні речовини не синтезуються в організмі, а потрапляють 3 їжею, водою та повітрям [1]. Збалансоване харчування 3 достатньою кількістю рослинних продуктів може задовольнити потребу в мінеральних речовинах і допомагає уникнути наслідків їх нестачі. 3 цього приводу є доцільним вивчення мінерального складу пастернаку посівного як 
харчової культури, що промислово культивується на території України.

Мета дослідження - визначити макро- і мікроелементний склад коренеплодів та плодів пастернаку посівного сорту "Петрик".

МЕТОДИ ДОСЛІДЖЕННЯ. Об'єкТОМ ДОслідження були висушені коренеплоди та плоди пастернаку посівного (Pastinaca sativa L.) сорту “Петрик", зібрані у 2016 р. Якісний склад та кількісний вміст макро- і мікроелементів визначали методом атомно-емісійної спектроскопії з фотографрічною реєстрацією в Науково-технологічному комплексі "Інститут монокристалів" НАН України.

Сировину обробляли кислотою сульфатною розведеною, потім зразок обвуглювали в муфельній печі при температурі не більше $500{ }^{\circ} \mathrm{C}$. Випаровування проби проводили при силі струму 16 А та експозиції 60 с. Спектри реєстрували на спектрографрі ДФС-8. Інтенсивність ліній у спектрах аналізованих проб і градуювальних зразків вимірювали з використанням мікрофротометра МФ-1 за таких умов: фраза підпалу $60{ }^{\circ} \mathrm{C}$; частота підпалювальних імпульсів - 100 розрядів/секунду; аналітичний проміжок - 2 мм; ширина щілини спектрографра - 0,015 мм. Спектри фоотографували в ділянці 230-330 нм. Фотопластинки проявляли, сушили, потім фотометрували наступні лінії (в нм) у спектрах проб і градуювальних зразків, а також фрон біля них. За градуювальним грасріком знаходили вміст елемента в золі. За фрормулою обчислювали кількісний вміст елемента $[4,5]$.

РЕЗУЛЬТАТИЙ ОБГОВОРЕННЯ. РЕЗУЛЬТаТИ кількісного визначення макро- і мікроелементів у коренеплодах та плодах пастернаку посівного наведені в таблиці.

Отримані експериментальні дані щодо макро- і мікроелементного складу коренеплодів та плодів пастернаку посівного свідчать про наявність у них не менше 19 елементів. У найбільшій кількості в коренеплодах містяться калій (2010,00 мг /100 г), кальцій (435,00 мг/100 г), магній (300,00 мг/100 г), натрій (270,00 мг/100 г), фроссрор (235,00 мг/100 г), у плодах переважає калій (1510,00 мг/кг). Крім того, в коренеплодах пастернаку посівного виявлено достатньо високий вміст цинку (13,40 мг/100 г). Як свідчать результати дослідження, лише 100 г коренеплодів пастернаку посівного задовольняють добову потребу людини в калію (близько 2000,00 мг/добу), магнію (200,00-400,00 мг/добу) та цинку (10,0015,00 мг/добу). Вміст інших елементів становить менше 0,1 мг/100 г. Кількісний вміст важких металів у коренеплодах пастернаку посівного перебуває в межах гранично допустимих концентрацій для сировини та харчових продуктів, а також відповідає вимогам ДФУ [6].

Таблиця - Вміст макро- і мікроелементів у коренеплодах та плодах пастернаку посівного сорту "Петрик"

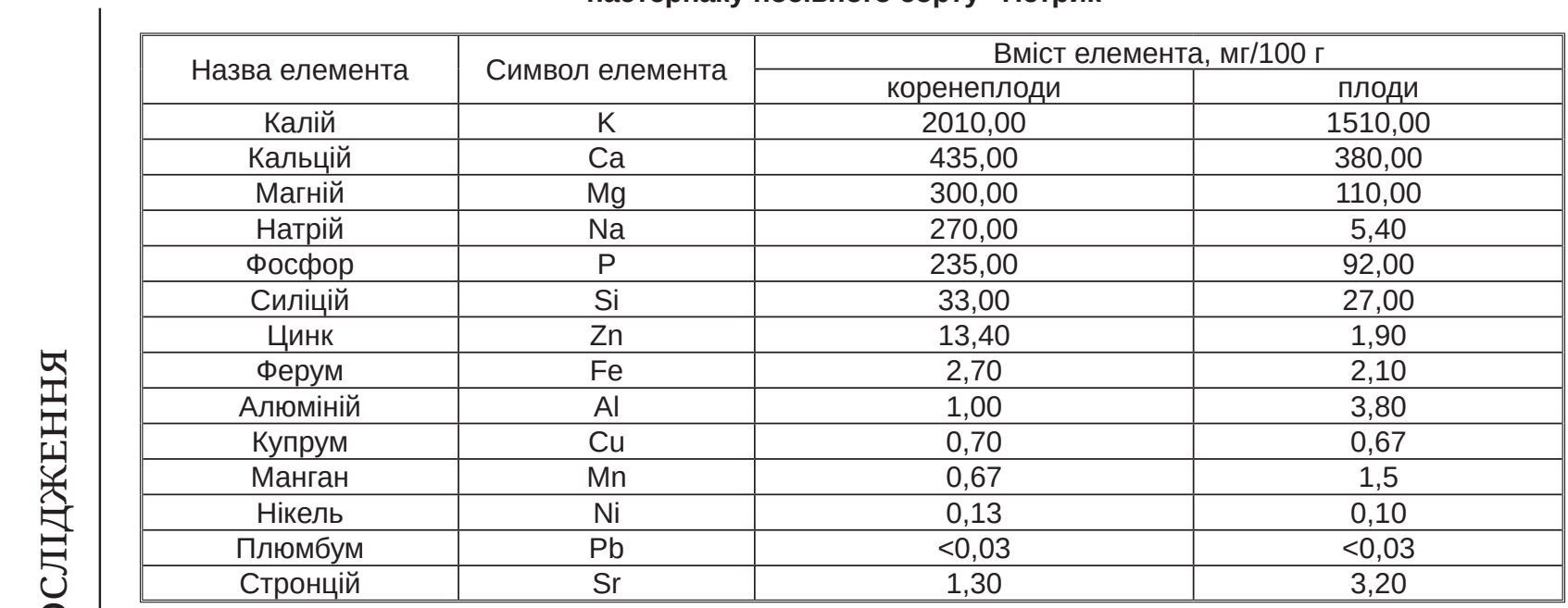

Примітка. Вміст (мкг/100 г) молібдену (Мо) <0,03; кобальту (Сo)<0,03; кадмію (Cd) <0,01; арсену (As) <0,01; меркурію $(\mathrm{Hg})<0,01$.

ВИСНОВКИ. Методом атомно-емісійної спектроскопії визначено макро- і мікроелементний склад коренеплодів та плодів пастернаку посівного сорту “Петрик". Експериментально виявлено не менше ніж 19 макро- і мікроелементів. У коренеплодах пастернаку посівного кількіс- но переважають калій (2010,00 мг/100 г), кальцій (435,00 мг/100 г), магній (300,00 мг/100 г), у плодах більше калію (1510,00 мг/100 г). Результати проведених досліджень будуть використані для подальших фрітохімічних досліджень сировини пастернаку посівного та розробки нових лікарських засобів на його основі. 


\section{СПИСОК ЛІТЕРАТУРИ}

1. Нагорная Н. В. Роль минеральных веществ в физиологии и патологии ребенка / Н. В. Нагорная, А. В. Дубовая, В. В. Алферов // Здоровье ребенка. 2008. - № 6. - C. 62-68.

2. Шаповалов С. О. Теоретичні та практичні аспекти ролі есенційних, біогенних, біофільних мікроелементів в організмі тварин / С. О. Шаповалов // Біологія та валеологія : зб. наук. праць Харк. нац. пед. ун-ту імені Г. С. Сковороди. - 2011. - Вип. 13. - С. 6979.

3. Макро- та мікроелементи (обмін, патологія та методи визначення) : монографія / [М. В. Погорєлов, В. І. Бумейстер, Г. Ф. Ткач та ін.]. - Суми : Вид-во СумДУ, 2010. - 147 с.

\section{REFERENCES}

1. Nagornaya, N.V., Dubovaya, A.V., Alferov, V.V., Meshcheryakova, A.V. \& Kharlap, I.V. (2008). Rol mineralnykh veshchestv $v$ fiziologii i patologii rebenka [The importance of mineral substances in the physiology and pathology of the child]. Zdorovye rebenka-Child's Health, 6, 62-68 [in Russian].

2. Shapovalov, S.O. (2011). Teoretychni ta praktychni aspekty roli esentsiinykh, biohennykh, biofilnykh mikroelementiv $v$ orhanizmi tvaryn [Theoretical and practical aspects of role of essential, biogenic, nutrients, trace elements in animals.]. Zbirnyk naukovykh prats Kharkivskoho natsionalnoho pedahohichnoho universytetu imeni H.S. Skovorody. Biolohiia ta valeolohiia - Scientific Journals of Kharkiv National Pedagogical University: H.S. Skovoroda Kharkiv National Medical University: Biology and Valeology, 13, 69-79 [in Ukrainian].

3. Pohorielov, M.V., Bumeister,V.I., \& Tkach H.F. (2010). Makro- ta mikroelementy (obmin, patolohiia ta metody vyznachennia): monohr. [Macro- and microelements (metabolism, pathology and determination methods): a monograph]. Sumy: Vyd-vo SumDU [in Ukrainian].
4. Зотікова О. А. Макро- та мікроелементний склад листя петрушки кучерявої, кореневої та листкової / О.А.Зотікова, В. С. Кисличенко, В.В.Вельма // Фармац. часоп. - 2012. - Вип. 4 (24). - С. 24-26.

5. Вельма В. В. Мінеральний склад коренеплодів петрушки кореневої / В.В.Вельма, В.С.Кисличенко // 3б. наук. праць співроб. НМАПО імені П. Л. Шупика. 2016. - Вип. 26. - С. 312-316.

6. Державна Фармакопея України : в 3 т. / Державне підприємство "Український науковий фрармакопейний центр якості лікарських засобів". - 2-ге вид. X. : Державне підприємство "Український науковий фармакопейний центр якості лікарських засобів", 2014. - 2. - 724 c.
4. Zotikova, O.A., Kyslychenko, V.S., \& Velma, V.S. (2012). Makro- ta mikroelementnyi sklad lystia petrushky kucheriavoi, korenevoi ta lystkovoi [Macro- and microelement content of curly, root and leaf parsley]. Farmatsevtychnyi chasopys. - Pharmaceutical Journal, 4 (24), 24-26 [in Ukrainian].

5. Velma, V.V. \& Kyslychenko, V.S. (2016). Mineralnyi sklad koreneplodiv petrushky korenevoi [Mineral composition of the root parsley roots]. Zbirnyk naukovykh prats spivrobitnykiv NMAPO imeni P.L.Shupyka - Collection of scientific works of staff member of P. L. Shupyk NMAPE, 26, 312-316 [in Ukrainian].

6. (2014). Derzhavna Farmakopeia Ukrainy: $v 3 t$. / Derzhavne pidpryiemstvo «Ukrainskyi naukovyi farmakopeinyi tsentr yakosti likarskykh zasobiv [State Pharmacopeia of Ukraine: in 3 vol. / State Enterprise "Ukrainian Scientific Pharmacopoeial Centre of Medicinal drugs Quality]. Kharkiv: Derzhavne pidpryiemstvo "Ukrainskyi naukovyi farmakopeinyi tsentr yakosti likarskykh zasobiv" [in Ukrainian].

Ю. Е. Шиморова, В. С. Кисличенко, В. Ю. Кузнецова НАЦИОНАЛЬНЫЙ ФАРМАЦЕВТИЧЕСКИЙ УНИВЕРСИТЕТ, ХАРЬКОВ

\section{МИНЕРАЛЬНЫЙ СОСТАВ КОРНЕПЛОДОВ И ПЛОДОВ ПАСТЕРНАКА ПОСЕВНОГО (РАSTINACA SATIVA L.) СОРТА “ПЕТРИК”}

\section{Резюме}

Вступление. Сохранение здоровья человека в условиях экозависимых патологий - самый актуальный вопрос современной медицины и фрармации. Наличие в организме определенных минеральных веществ в соответствующем количестве - одно из условий поддержания и сохранения здоровья человека. Несмотря на то, что минеральные вещества не имеют энергетической ценности, как белки, жиры и углеводы, много фрерментативных процессов в организме невозможно без их участия. Таким образом, важнейшие фрункции живого организма - реализация генетической информации, образование субклеточных структур, метаболические процессы, выработка энергии, фрункционирование всех органов и систем - зависят от количественного и качественного содержания в организме минеральных веществ. 
Цель исследования - определить макро- и микроэлементный состав корнеплодов и плодов пастернака посевного сорта "Петрик".

Методы исследования. Качественное и количественное содержание макро- и микроэлементов высушенных корнеплодов и плодов пастернака посевного (Pastinaca sativa L.) copma “Петрик” определяли методом атомно-эмиссионной спектроскопии с фотографической регистрацией в Научно-технологическом комплексе "Институт монокристаллов" НАН Украины.

Результаты и обсуждение. Полученные экспериментальные данные относительно макро- и микроэлементного состава корнеплодов и плодов пастернака посевного свидетельствуют о наличии в них не менее 19 элементов. В наибольшем количестве в корнеплодах содержатся калий (2010,00 мг/100 г), кальций (435,00 мг/100 г), магний (300,00 мг/100 2), натрий (270,00 мг/100 2), фросфрор (235,00 мг/100 г), в плодах преобладает калий (1510,00 мг/кг). Кроме того, в корнеплодах пастернака посевного обнаружено достаточно высокое содержание цинка (13,40 мг/100 2). Содержание других элементов составляет менее $0,1 \mathrm{M2} / 100$ 2.

Выводы. Методом атомно-эмиссионной спектроскопии в корнеплодах и плодах пастернака посевного сорта "Петрик" обнаружено не менее 19 макро- и микроэлементов. В корнеплодах пастернака посевного количественно преобладают калий (2010,00 мг/100 2), кальций (435,00 мг/100 г), магний (300,00 мг/100 г), в плодах больше калия (1510,00 мг/100 2). Результаты проведенных исследований будут использованы для последующих фритохимических исследований сырья пастернака посевного и разработки новых лекарственных средств на его основе. троскопия.

КЛЮЧЕВЫЕ СЛОВА: пастернак посевной; макро- и микроэлементы; атомно-эмиссионная спек-

J. E. Shimorova, V. S. Kyslychenko, V. Yu. Kuznietsova NATIONAL UNIVERSITY OF PHARMACY, KHARKIV

\section{MINERAL COMPOSITION OF PARSNIP (PASTINACA SATIVA L.) ROOTS AND FRUITS “PETRIK” VARIETY}

\section{Summary}

Introduction. Human health preserving in an environment of eco-depending pathologies is the most important issue of modern medicine and pharmacy. The presence of certain mineral substances in the body in an appropriate quantity is one of the conditions for maintaining and preserving human health. Despite the fact that minerals do not have energy value, like proteins, fats and carbohydrates, many enzymatic processes in the body are impossible without their participation. Thus, the most important functions of a living organism are the realization of genetic information, the formation of subcellular structures, metabolic processes of energy production, the functioning of all organs and systems, depend on the quantitative and qualitative content of mineral substances in the body.

The aim of the study - to determine macro- and microelement composition of parsnip`s roots and fruits of "Petrik" variety.

Research Methods. Determination of the qualitative and quantitative composition of macro- and microelements of dried parsnip`s roots and fruits - Pastinaca sativa L. "Petrik" variety was carried out by atomic-emission spectroscopy with photographic registration in the State scientific institution "Institute for single crystals" of National Academy of Sciences of Ukraine.

Results and Discussion. 19 elements were detected as a result of experimental studies. The roots predominantly contains potassium (2010.00 mg of /100 g), calcium (435.00 mg/100g), magnesium (300.00 mg/100g), sodium (270.00 mg/100 g), phosphorus (235.00 mg/100g); in fruits - potassium (1510.00 mg/kg). Roots are rich on zinc $(13.40 \mathrm{mg} / 100 \mathrm{~g})$. Content of other elements are less than $0.1 \mathrm{mg} / 100 \mathrm{~g}$.

Conclusions. 19 elements were found in the roots and fruits of parsnip. Potassium (2010.00 mg/100g), calcium (435.00 mg/100g), magnesium (300.00 mg/100g) are dominated in the roots of parsnip; potassium is dominated in fruits $(1510.00 \mathrm{mg} / 100 \mathrm{~g})$. The results of the research will be used for further phytochemical studies of parsnip and the development of new drugs on is base.

\section{KEY WORDS: parsnip; macro- and microelements; atomic emission spectroscopy.}

Отримано 28.04.17

Адреса для листування: В. С. Кисличенко, Національний фармацевтичний університет, вул. Пушкінська, 53, Харків, 61002, україна, e-mail: cnc@nuph.edu.ua. 